\title{
Stimulation of Sertoli cell proliferation: defining the response interval to an inhibitor of estrogen synthesis in the boar
}

\author{
Trish Berger ${ }^{1}$, Lisa Kentfield ${ }^{1}$, J F Roser ${ }^{1}$ and Alan Conley ${ }^{2}$ \\ Departments of ${ }^{1}$ Animal Science and ${ }^{2}$ Population Health and Reproduction, University of California, Davis, \\ California 95616, USA \\ Correspondence should be addressed to T Berger; Email: tberger@ucdavis.edu
}

\begin{abstract}
Sertoli cell proliferation occurs in two major waves after birth, one neonatally and another prepubertally, each contributing to final testicular size and sperm production. However, little is known about the regulation of either wave. We have previously shown that letrozole, an inhibitor of estrogen synthesis, increases Sertoli cell number and testicular size at sexual maturity in boars. These studies were conducted to determine whether letrozole affects the first or second proliferative wave. Boars were treated with letrozole during the first wave (treatment at 1, 3, and 5 weeks), less frequently ( 1 week of age only, or 1 and 5 weeks), on postnatal day 1 , or during the second wave (weeks 11-16). Sertoli cells were enumerated in testes and estrogen concentrations were evaluated in serum and testes. Compared with vehicle controls, letrozole reduced estrogen in boars treated at weeks 1 and 5 or 1,3 , and 5 , on postnatal day 1, or prepubertally. However, Sertoli cell numbers were increased only in boars treated at 1, 3, and 5 weeks of age. Neither perinatal (1 day old) nor prepubertal letrozole treatment affected Sertoli cell numbers. Hence, Sertoli cell proliferation was sensitive to letrozole only if letrozole was administered throughout the first wave, even though estrogen synthesis was effectively inhibited at all ages. These data indicate that the neonatal but not the prepubertal window of Sertoli cell proliferation is sensitive to an inhibitor of estrogen synthesis; this suggests that these two waves are differently regulated.
\end{abstract}

Reproduction (2012) 143 523-529

\section{Introduction}

Sperm production capacity and testicular size in mammals are positively correlated with size of the Sertoli cell population (Berndtson et al. 1987). Hence, increased understanding of Sertoli cell proliferation and development is important to those interested in animal agriculture. As abnormalities in Sertoli cell development and proliferation contribute to testicular dysgenesis syndrome in humans (Wohlfahrt-Veje et al. 2009), increased understanding is also important to the biomedical community. Previous studies in our laboratory have demonstrated that the administration of letrozole, an inhibitor of estrogen synthesis, beginning in the neonatal period promotes proliferation of Sertoli cells in boars. This results in an $\sim 25 \%$ increase in Sertoli cell number, testicular weight, and sperm production (At-Taras et al. 2006a, Berger et al. 2008). Mechanisms regulating this increase are not yet well understood, although existing data suggest local rather than systemic mediation (At-Taras et al. 2006b).

Compensatory testicular growth is a well-recognized response to hemicastration. In boars, the degree to which growth of the remaining testis is stimulated depends on the age of the boar (Putra \& Blackshaw 1982, 1985,
Lunstra et al. 2003, Ford et al. 2010). Although the earlier the age of hemicastration, the greater is the weight of the remaining testis at maturity; the remaining testis never exceeds the weight or sperm production equivalent to two mature testes. Testicular size can be increased in some rodents by transient neonatal hypothyroidism, but induced hypothyroidism has not had an effect in pigs suggesting species differences in regulatory mechanisms (Hess et al. 1993, Joyce et al. 1993, Tarn et al. 1998, Klobucar et al. 2003, Jansen et al. 2007). In contrast, letrozole treatment in developing boars promotes testicular growth and sperm production that significantly exceeds that of untreated boars. As such, letrozole treatment offers the potential to enhance the reproductive capacity of mature boars, and may provide insights into the regulation of Sertoli cell proliferation in mammals using this high endogenous estrogen male. However, the developmental interval(s) of response (age dependence) is undefined.

During normal development, Sertoli cells are believed to complete proliferation prepubertally and undergo differentiation/maturation before lumen formation within seminiferous tubules. Postnatal proliferation of Sertoli cells occurs in two waves during the prepubertal interval (Franca et al. 2000, Sharpe et al. 2003). The first 


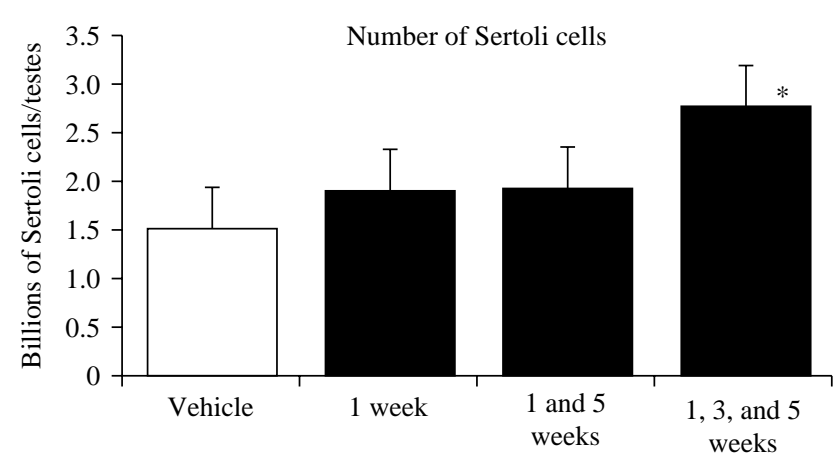

Age at treatment with letrozole

Figure 1 Number of Sertoli cells per testes at 6.5 weeks of age following treatment with letrozole (filled bar) or with vehicle (open bar) between 1 and 5 weeks of age. ${ }^{*} P<0.05$, from ANOVA followed by linear contrasts comparing vehicle controls and letrozole-treated littermates. Values represent least squares means for four boars except the 1-, 3-, and 5 -week value, which is the mean of three boars from three different litters.

wave of Sertoli cell proliferation in Piau pigs is reported to occur before 1 month and the second wave just before puberty, between 3 and 4 months of age. Whether these two waves of proliferation are regulated by similar physiological cues is unknown. Similarly, while continuous inhibition of aromatase activity led to an $\sim 25 \%$ increase in number of Sertoli cells and testicular weight in boars after sexual maturity (At-Taras et al. 2006a), whether this had differential effects on the first and second wave is unknown. In our previous studies (At-Taras et al. 2006a, Berger et al. 2008), the effects of letrozole on Sertoli cell proliferation in the first wave could not be distinguished from the effects on the second, prepubertal wave of proliferation. Understanding the time intervals when Sertoli cells are sensitive to this treatment and when they are insensitive is critical for further studies investigating mechanism(s) by which aromatase inhibition influences Sertoli cell proliferation, postpubertal testicular size, and sperm production. The current studies were designed to evaluate the effects of letrozole administered during each of the two postnatal waves of Sertoli cell proliferation, thereby providing insight into the physiological regulation of this process.

\section{Results}

Boars treated with letrozole at 1, 3, and 5 weeks of age had significantly more Sertoli cells at 6.5 weeks of age than their littermates receiving the canola oil vehicle (Fig. 1) or littermates treated only at 1 week of age. Sertoli cell density was similarly increased (Table 1 ). Testicular tissue levels of estradiol $\left(\mathrm{E}_{2}\right)$ were dramatically reduced by treatment at 1,3 , and 5 weeks and by treatment at 1 and 5 weeks (Fig. 2). Levels of LH or FSH in the circulation did not vary among treatments (Table 1 ).

Boars treated with letrozole at 1 day of age exhibited markedly reduced circulating $E_{2}$ at 9 days of age at time of tissue retrieval $(13.7 \mathrm{pg} / \mathrm{ml}$ compared with 38.8 for vehicle control littermates). Sertoli cell numbers per testis were similar between the vehicle controls and the letrozole-treated littermates at 9 days of age (0.21 vs 0.15 billion per testis, respectively, S.E.M. $=0.04$ ). Proliferation rate for Sertoli cells at 9 days of age assessed by percentage of phosphorylated histone 3-labeled cells (Fig. 3) was also similar between vehicle controls and letrozole-treated littermates (7.8 and 8.0\%, S.E.M. $=0.3$ ). No effects of treatment on circulating testosterone, $\mathrm{LH}$, or FSH were observed (Table 2).

In contrast to boars treated from 1 to 5 weeks of age, the number of Sertoli cells per testis was similar in boars treated with letrozole from 11 to 15 weeks and vehicle control littermates at 16 weeks of age (Fig. 4) and remained similar at 20 and 40 weeks of age. Despite the insensitivity of Sertoli cell numbers to letrozole treatment from 11 to 16 weeks of age, testicular aromatase activity at 16 and 20 weeks of age was dramatically reduced by the treatment (Fig. 5). Although aromatase activity was arithmetically lower in 40-week boars treated with letrozole from 11 to 16 weeks of age compared with vehicle control littermates, this apparent reduction was not significant. The effect on aromatase was reflected in estrogen concentration. Circulating $\mathrm{E}_{2}$ levels were markedly reduced within 1 week of treatment (24 vs $11 \mathrm{pg} / \mathrm{ml}$, S.E.M. $=4, P<0.01$ ), demonstrating an immediate effect on aromatase activity, and testicular $E_{2}$ and, estrogen conjugates were reduced at 16 and 20 weeks of age (Figs 6 and 7). Testicular tissue levels of testosterone

Table 1 Characteristics of male pigs at 6.5 weeks of age.

\begin{tabular}{|c|c|c|c|c|c|}
\hline & Vehicle & $\begin{array}{l}\text { Letrozole } \\
\text { (1 week) }\end{array}$ & $\begin{array}{c}\text { Letrozole } \\
\text { (1 and } 5 \text { weeks) }\end{array}$ & $\begin{array}{c}\text { Letrozole } \\
(1,3, \text { and } 5 \text { weeks })\end{array}$ & S.E.M. \\
\hline Plasma $E_{2}(p g / m l)^{a}$ & 10.9 & 12.3 & 8.4 & 7.4 & 2 \\
\hline Plasma testosterone $(\mathrm{ng} / \mathrm{ml})^{\mathrm{b}}$ & 0.7 & 1.4 & 1.7 & 1.9 & 0.2 \\
\hline $\mathrm{LH}(\mathrm{ng} / \mathrm{ml})$ & 2.08 & 2.88 & 1.19 & 1.42 & 1.04 \\
\hline $\mathrm{FSH}(\mathrm{ng} / \mathrm{ml})$ & 5.48 & 6.60 & 5.95 & 6.78 & 0.75 \\
\hline Sertoli cell density $\left(\times 10^{6} / \mathrm{cm}^{3}\right)$ & 118 & 130 & 150 & 167 & 24 \\
\hline Testes weight $(\mathrm{g})^{\mathrm{c}}$ & 12.50 & 14.84 & 12.56 & 17.4 & 1.94 \\
\hline
\end{tabular}

${ }^{a}$ Values previously reported (Corbin et al. 2009); $400 \mu \mathrm{l}$ sample volumes extracted with ether to lower assay detection limit to $5 \mathrm{pg} / \mathrm{ml}$ but values in some samples were lower. ${ }^{b}$ Values previously reported (Corbin et al. 2009). ${ }^{\mathrm{c}}$ Testes weight for boars treated with letrozole at 1,3 , and 5 weeks of age differed from littermates treated with vehicle, $P<0.05$. 


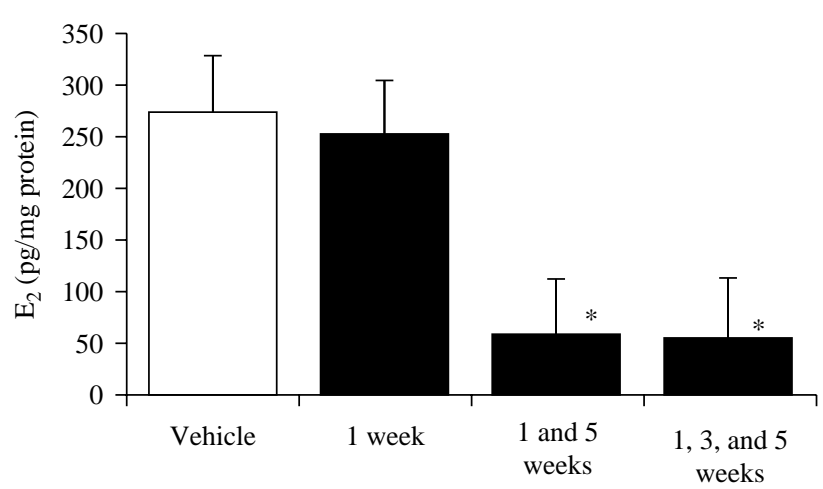

Age at treatment with letrozole

Figure 2 Estradiol concentration in testicular tissue at 6.5 weeks of age following treatment with letrozole (filled bar) or with vehicle (open bar). ${ }^{*} P<0.05$, from ANOVA followed by linear contrasts comparing vehicle controls and letrozole-treated littermates. Values represent least squares means for four boars except the 1-, 3-, and 5-week value, which is the mean of three boars from three different litters.

(Table 3) and circulating $\mathrm{LH}$ and FSH concentrations were not altered by treatment $(1.2 \mathrm{vs} 1.6 \mathrm{ng} \mathrm{LH} / \mathrm{ml}$, S.E.M. $=0.3$, and 7.1 vs $7.6 \mathrm{ng} \mathrm{FSH} / \mathrm{ml}$, S.E.M. $=0.5$ in 12 - to 14-week vehicle control vs letrozole-treated animals respectively). Neither testicular sperm production (detergent-resistant spermatid numbers) nor testis weight was different between treated and control boars at any age in this experiment (Table 3).

\section{Discussion}

The results of the data reported here not only define the period of Sertoli cell proliferation that is responsive to inhibition of aromatase but also provide insight into the regulation of the process and its age dependence. The letrozole-induced increase in Sertoli cell numbers at 6.5 weeks in boars treated at 1,3 , and 5 weeks mirrors the results of a previous study in which boars were treated with letrozole continuously through 8 months of age (At-Taras et al. 2006a), and when treatment was restricted to the first 3 months of life (Berger et al. 2008). Just as importantly, the absence of effect in boars treated only at 1 day of age, 1 week of age only, 1 and 5 weeks of age, or between 11 and 16 weeks of age clearly defines the period during which Sertoli cell proliferation in the boar is sensitive to an aromatase inhibitor. The sensitive interval is neither perinatal nor peripubertal, and sensitivity requires letrozole exposure to be present at 3 weeks of age. This suggests that the letrozole effect is either mediated over a prolonged interval or after 3 weeks postnatally. The lack of an effect of letrozole treatment on 1-day-old boars is of interest because rapid rates of Sertoli proliferation have been reported for this early postnatal interval (McCoard et al. 2001). Our data suggest that proliferation during the immediate postnatal interval is not sensitive to aromatase inhibition but becomes responsive after the first 3 weeks of life. This is a developmental interval during which endogenous circulating estrogen concentrations are declining naturally (Ford 1983, Schwarzenberger et al. 1993) and may define the important period of Sertoli cell proliferation in a physiological context also. The reduced estrogen concentrations in tissues and serum of letrozole-treated boars confirmed that the lack of response during this interval was not due to a failure of the drug to inhibit estrogen synthesis, suggesting that there must be a change in the responsiveness that affects Sertoli cell proliferation itself. Whether this is due to neonatal changes in steroid receptor expression or changes in other components of the response pathway remain to be determined; both ESR1 and ESR2 are present in Sertoli cells and peritubular myoid cells (Ramesh et al. 2007). Despite the inhibition of estrogen, testosterone concentrations were not significantly altered. Testosterone is the immediate substrate for $\mathrm{E}_{2}$ synthesis by P450arom, and inhibition of aromatase activity might be thought to result in an accumulation of substrate. However intuitive, previous studies on enzyme activities in testes of neonatal boars, specifically aromatase and 17,20lyase, the last and limiting step in androgen synthesis, indicate that a 100-fold difference exists between the two in favor of 17,20-lyase (Moran et al. 2002). Such a large differential predicts that inhibition of P450arom would impact only a small fraction of the androgen substrate that would otherwise undergo aromatization; hence, little change in testosterone would be expected.
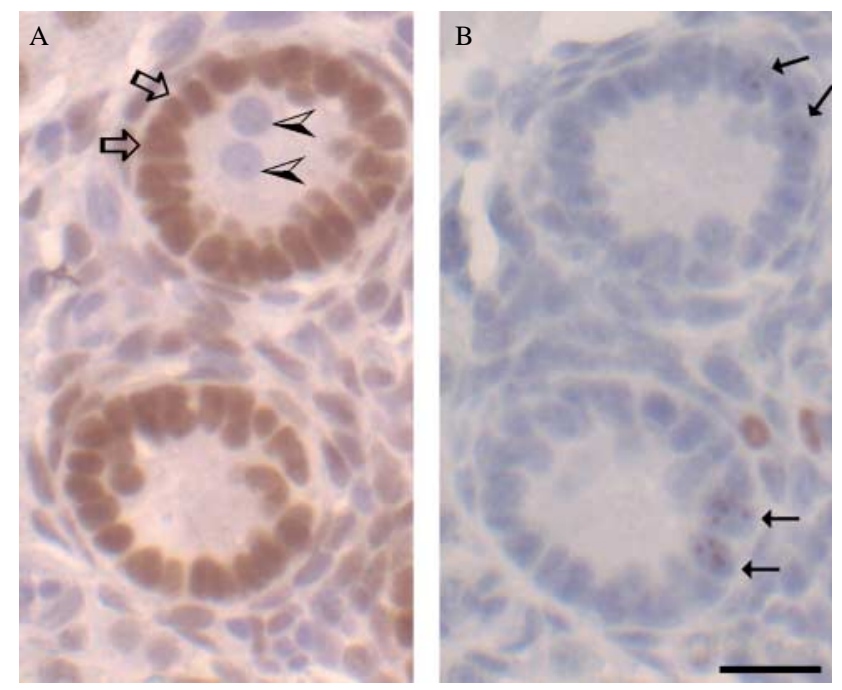

Figure 3 Serial sections of boar testis at 9 days of age.

(A) Immunohistochemically labeled section by antibody to GATA4 to identify Sertoli cells. Open arrows point to two of the many Sertoli cells in this image, characterized by elongated nuclei either perpendicular to or parallel with the basement membrane and arranged at the periphery of the seminiferous tubule. Arrow heads point to germ cells characterized by round nuclei, significant cytoplasm, unlabeled by the GATA4 antibody and frequently centrally located at this age. (B) Immunohistochemically labeled section with an antibody to phosphorylated histone 3 to detect proliferating cells. Small, solid arrows point to four labeled Sertoli cells. Bar represent $20 \mu \mathrm{m}$. 
Table 2 Characteristics of male pigs at 9 days of age.

\begin{tabular}{lccc}
\hline & Vehicle & Letrozole & s.E.M. \\
\hline Plasma testosterone $(\mathrm{ng} / \mathrm{ml})$ & 0.68 & 0.70 & 0.06 \\
$\mathrm{LH}(\mathrm{ng} / \mathrm{ml})$ & 2.8 & 2.2 & 0.4 \\
FSH $(\mathrm{ng} / \mathrm{ml})$ & 8.7 & 9.0 & 1.5 \\
Sertoli cell density $\left(\times 10^{6} / \mathrm{cm}^{3}\right)$ & 81 & 84 & 12 \\
Testes weight $(\mathrm{g})$ & 5.10 & 3.64 & 0.61 \\
\hline
\end{tabular}

The current and previous observations in boars treated with letrozole are consistent with this prediction.

Interestingly, the second wave of Sertoli cell proliferation was not sensitive to aromatase inhibition. There were no indications of increased Sertoli cell numbers immediately after aromatase inhibition from weeks 11-15 near the end of the second wave nor did any develop at 20 or 40 weeks of age postpubertally. This was despite inhibition of testicular aromatase and concomitantly reduced estrogens in effect through 20 weeks of age. Hence, future experiments designed to evaluate and manipulate Sertoli cell proliferation by reducing endogenous estrogens should focus on the first wave, including the latter part of the first wave of proliferation. This idea is consistent with the hypothesis that reducing endogenous estrogens prolongs the first wave of Sertoli cell proliferation (Kao D \& Berger $\mathrm{T}$, unpublished observations). A similar explanation of prolonged interval for proliferation was suggested for the difference in Sertoli cell numbers between slower maturing boars with large testes and more rapidly maturing boars with smaller testes (Lunstra et al. 2003). In addition, as current and previous evidence support local testicular mediation rather than systemic mediation of the stimulus on Sertoli cell proliferation, these observations suggest that regulation of proliferation differs between the first and second waves.

Another experimental strategy to increase testis size is hemicastration. The circulating levels of $\mathrm{FSH}$ are increased for several weeks following hemicastration and are believed to mediate the Sertoli cell proliferation that follows (Kosco et al. 1987). In contrast, we did not

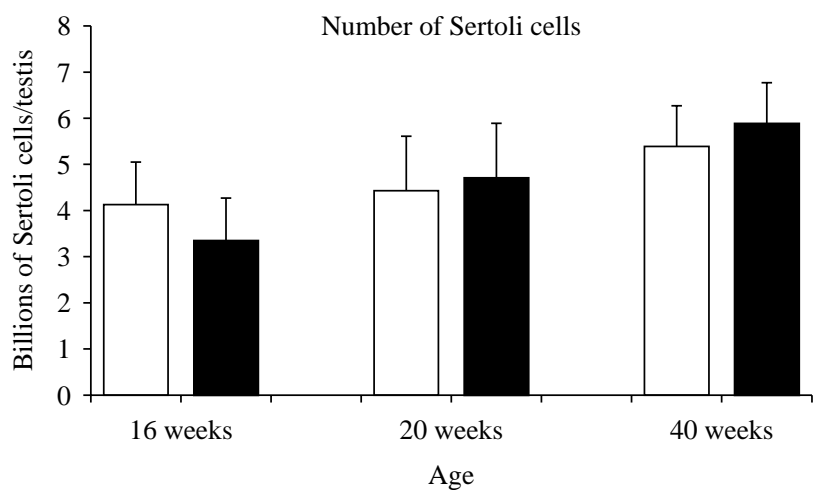

Figure 4 Least squares means for number of Sertoli cells per testis peripubertally and postpubertally following treatment between 11 and 16 weeks of age. Open bars represent vehicle control littermates, filled bars represent letrozole-treated littermates, $n=5$ per group.

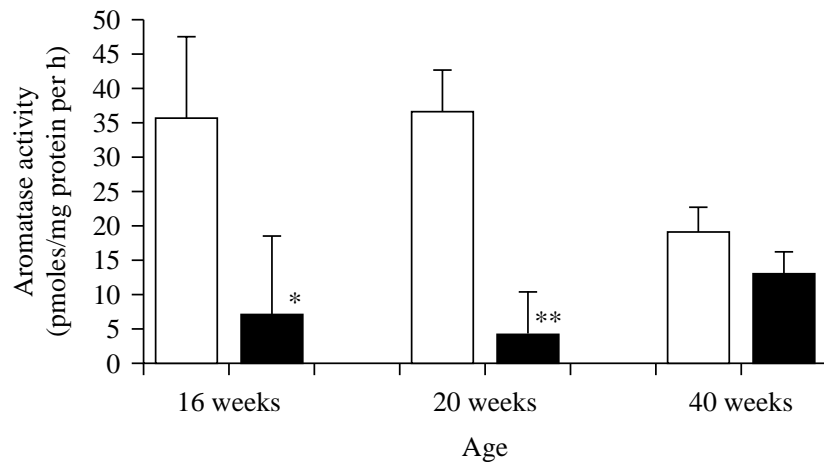

Figure 5 Least squares means for testicular aromatase activity peripubertally and postpubertally following treatment between 11 and 16 weeks of age. Open bars represent vehicle control littermates and filled bars represent letrozole-treated littermates, $n=5$ per group. ${ }^{*} P<0.05,{ }^{* *} P<0.01$ from ANOVA followed by linear contrasts comparing vehicle controls and letrozole-treated littermates of same age.

detect an increase in $\mathrm{FSH}$ at 9 days of age, at 6.5 weeks of age, or following treatment from 11 to 16 weeks of age. In fact, these and previous data from our laboratory have found no evidence of an increase in $\mathrm{FSH}$ as part of the short-term or the long-term response to letrozole (At-Taras et al. 2006b). This suggests that estrogen does not play a significant role in negative feedback of the hypothalamic-pituitary axis in boars (At-Taras et al. 2006a) and that the testicular response to letrozole does not include an increase in FSH drive. Thus, the increase in testis size and sperm production at sexual maturity in response to hemicastration likely involves different mechanisms than those driving the response to letrozole.

The results of the current studies confirm that the first wave of Sertoli cell proliferation is sensitive to endogenous estrogens. As we previously observed, reduction of endogenous estrogens increased Sertoli cell proliferation. Furthermore, these results suggest that letrozole treatment is most effective after 3 weeks of age. These experiments were the first to evaluate sensitivity of Sertoli cell proliferation during the interval corresponding to the second wave independent of the first wave and demonstrated that the second wave of Sertoli cell proliferation was not sensitive to endogenous estrogens in pigs.

\section{Materials and Methods}

\section{Animals and treatment}

Sensitivity of the first wave of Sertoli cell proliferation to inhibition of aromatase independent of the second wave was evaluated in two experiments. Letrozole (CGS 20 267; 4-40(1 H-1,2,4-triazol-1-yl-methylene)-bis-benzonitrile; CibaGeigy, Basel, Switzerland), a nonsteroidal aromatase inhibitor, was used in these studies as in our previous studies. Response to letrozole treatment during weeks $1-5$ of age was investigated in the first experiment. Although endogenous estrogens are suppressed for at least 4 weeks following treatment in a mature 


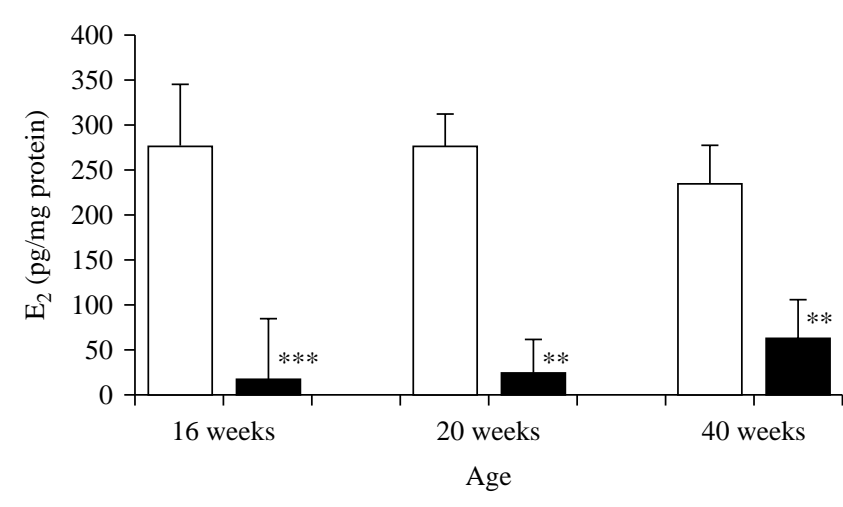

Figure 6 Least squares means for testicular $E_{2}$ concentrations peripubertally and postpubertally following treatment between 11 and 16 weeks of age. Open bars represent vehicle control littermates and filled bars represent letrozole-treated littermates, $n=5$ per group. ${ }^{* *} P<0.01,{ }^{* * *} P<0.001$ from ANOVA followed by linear contrasts comparing vehicle controls and letrozole-treated littermates of same age.

boar (Berger et al. 2008), we hypothesized that effective inhibition might be shorter in growing animals. Inhibition for 2 weeks following a single oral dose of letrozole treatment was verified (preliminary data not shown); hence, treatment every other week was the most frequent treatment used for the piglets treated between 1 and 5 weeks of age. A boar was randomly assigned to receive $0.1 \mathrm{mg}$ letrozole/ $\mathrm{kg}$ body weight orally at 1,3 , and 5 weeks of age, a second littermate to receive the same dose at 1 and 5 weeks of age, the third littermate to receive that dose only at 1 week of age, and the fourth to receive the canola oil vehicle. Additional littermates were randomly assigned to one of the preceding treatments. Animals were weighed before treatment and 15 boars from three litters completed the study. At 6.5 weeks of age, animals were weighed, blood samples were obtained, animals were killed (86 mg pentobarbital sodium/kg body weight, Vortech Pharmaceuticals, Dearborn, MI, USA), and tissues were retrieved following killing. Testes were weighed, one sample was fixed in $4 \%$ paraformaldehyde for determination of Sertoli cell density, and a second sample was frozen on dry ice for subsequent determination of testicular steroid levels. Hypothalamic and testicular aromatase activities were previously reported for these boars (Corbin et al. 2009).

The second experiment further investigated the initial phase of the first wave of Sertoli cell proliferation. One member of each littermate pair of boars was randomly assigned to receive letrozole at 1 day of age and the other littermate received the oil vehicle. Blood samples were obtained and testicular tissue was retrieved at 9 days of age following killing. Testes were weighed and a sample was fixed in $4 \%$ paraformaldehyde for determination of Sertoli cell density and Sertoli cell proliferation.

The sensitivity of the second wave of Sertoli cell proliferation to reduced aromatase activity was evaluated in a third experiment. Littermate sextets of boars were randomly assigned to treatment with the aromatase inhibitor letrozole (three littermates) or the canola oil vehicle control (three littermates). Weekly treatment began at 11 weeks of age and continued through 16 weeks of age. Boars were weighed and food withdrawn for $\sim 3 \mathrm{~h}$ before dosing. For treatment, boars were introduced individually to pens and a small amount of feed (100 g) was top-dressed with canola oil vehicle or letrozole suspended in canola oil vehicle to provide $0.1 \mathrm{mg}$ letrozole $/ \mathrm{kg}$ body weight (or the equivalent amount of oil). Blood samples were obtained at 12 and 14 weeks of age as well as following killing by electrocution. Tissues were recovered from one treated and one vehicle control boar from each litter at 16 weeks of age (treated weekly from 11 to 15 weeks of age), 20 weeks of age, and 40 weeks of age. Testes were weighed, two pieces of testis from each boar were processed as described for the 6.5 week boars, and a third sample of $1 \mathrm{~g}$ was stored at $-17^{\circ} \mathrm{C}$ until homogenization for determination of detergentresistant spermatids. This experiment was replicated using six littermate boars from each of five different litters.

Boars in experiments 1 and 3 were of Sygen ancestry and derived from breeding stock and semen donated by PIC USA (Franklin, KY, USA). The boars used in experiment 2 were crossbred with Yorkshire sires. All animals were used in accordance with Guide for the Care and Use of Agricultural Animals in Agricultural Research and Teaching and approved by the Institutional Animal Care and Use Advisory Committee.

\section{Hormone assays}

Blood was collected by jugular venipuncture in $10 \mathrm{ml}$ vacutainer tubes, cooled to $4{ }^{\circ} \mathrm{C}$, centrifuged at $\sim 1300 \mathrm{~g}$ for $10 \mathrm{~min}$, aliquoted, and plasma was stored at $-20^{\circ} \mathrm{C}$ until assayed. Testis tissue (stored at $-80^{\circ} \mathrm{C}$ ) was homogenized in 10 volumes of homogenization buffer $(0.1 \mathrm{M}$ potassium phosphate buffer ( $\mathrm{pH} 7.4$ ) containing $20 \%$ glycerol, $5 \mathrm{mM}$ $\beta$-mercaptoethanol, and $0.5 \mathrm{mM} 4$-(2-aminoethyl)benzenesulfonyl fluoride hydrochloride (AEBSF) (Sigma; Corbin et al. 1999, Moran et al. 2002), sonicated for $3 \mathrm{~s}$, and centrifuged at $15000 \mathrm{~g}$ for $10 \mathrm{~min}$. Tissue supernate was analyzed for protein concentration using a Coomassie dye (Coomassie Protein Assay Kit, Thermo Fisher Scientific, Inc., Rockford, IL, USA) and stored at $-20{ }^{\circ} \mathrm{C}$ until assayed for $\mathrm{E}_{2}$, estrogen conjugates, and testosterone. Plasma concentrations of $E_{2}$, estrogen conjugates, testosterone, $\mathrm{LH}$, and $\mathrm{FSH}$ and testicular tissue

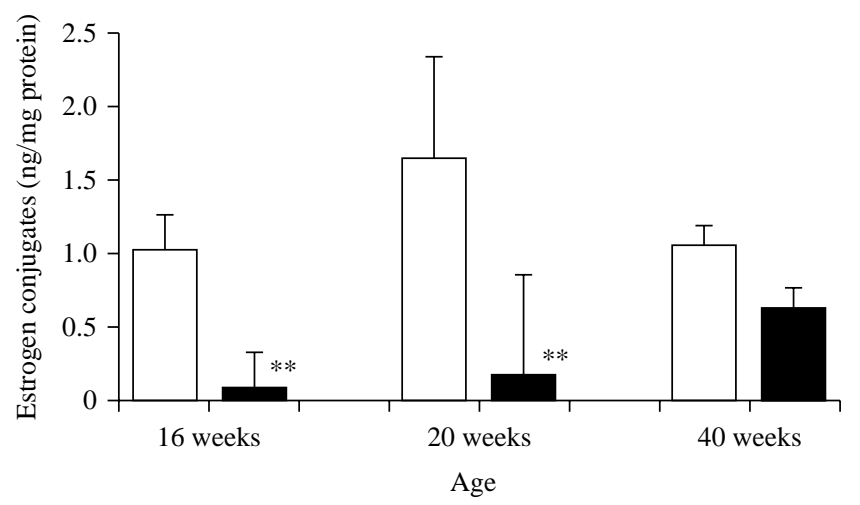

Figure 7 Least squares means for testicular estrogen conjugate concentrations peripubertally and postpubertally following treatment between 11 and 16 weeks of age. Open bars represent vehicle control littermates and filled bars represent letrozole-treated littermates, $n=5$ per group. ${ }^{* *} P<0.01$ from ANOVA followed by linear contrasts comparing vehicle controls and letrozole-treated littermates of same age. 
Table 3 Characteristics of male pigs treated between 11 and 16 weeks of age with letrozole or vehicle.

\begin{tabular}{|c|c|c|c|c|c|c|c|c|c|}
\hline & \multicolumn{9}{|c|}{ Age } \\
\hline & \multicolumn{3}{|c|}{16 weeks } & \multicolumn{3}{|c|}{20 weeks } & \multicolumn{3}{|c|}{40 weeks } \\
\hline & Vehicle & Letrozole & S.E.M. & Vehicle & Letrozole & S.E.M. & Vehicle & Letrozole & S.E.M. \\
\hline Testicular testosterone (ng/mg protein) & 10.0 & 6.8 & 5.2 & 1.7 & 3.0 & 0.8 & 1.4 & 1.0 & 0.5 \\
\hline Sertoli cell density $\left(\times 10^{6} / \mathrm{cm}^{3}\right)$ & 42.4 & 42.6 & 10.1 & 17.9 & 20.9 & 2.9 & 13.2 & 14.9 & 1.8 \\
\hline Testes weight (g) & 191.4 & 167.3 & 26.3 & 482.8 & 429.6 & 75.1 & 789.6 & 759.8 & 40.1 \\
\hline Detergent-resistant spermatids ( $\times 10^{8} /$ testis $)$ & 0.56 & 0.16 & 0.24 & 72.0 & 66.9 & 9.2 & 145 & 178 & 16 \\
\hline
\end{tabular}

concentrations of $E_{2}$, estrogen conjugates, and testosterone were measured in duplicate by RIA as previously validated in the pig (At-Taras et al. 2006b). $\mathrm{E}_{2}$ was measured using a sheep anti- $E_{2} 17 \beta-6$-BSA antibody (Niswender \#224; G Niswender, Colorado State University, Fort Collins, CO, USA), tritiated $\mathrm{E}_{2}$ (NET-317; Perkin Elmer Life Sciences, Boston, MA, USA), and $\mathrm{E}_{2}$ standards (E950; Steraloids, Wilton, NH, USA). Testosterone was measured using a sheep anti-testosterone antibody (Niswender \#S250), 3H-testosterone (NET370; Perkin Elmer Life Sciences), and testosterone standards (A6940; Steraloids). Samples were extracted with ethyl ether for both $E_{2}$ and testosterone assays and extraction efficiencies ranged between 71 and $88 \%$. Estrogen conjugates were measured using rabbit anti-estrone-3-glucuronide (Munro R-583, 1:12 000 dilution; courtesy of C J Munro, Clinical Endocrinology Laboratory, University of California, Davis, CA, USA) and tritiated estrone sulfate (estrone sulfate [6,7-3H(N)], NET203; Perkin Elmer). The LH RIA used a mouse monoclonal anti-bovine LH (518B7, Roser) and porcine LH (EX275A, Papkoff) standards and the FSH RIA used rabbit anti-porcine FSH (R285; courtesy of $\mathrm{H}$ Papkoff, University of California, Davis, CA, USA) and iodinated porcine FSH (EX274B, Papkoff) standards. The sensitivity and intra- and interassay coefficients of variation (CV) for $\mathrm{E}_{2}$ were $10 \mathrm{pg} / \mathrm{ml}, 11.2$ and $9.9 \%$. Cross-reactivity for this antibody with estrone is $3 \%$ (Korenman et al. 1974). The sensitivity and intra- and interassay CV for testosterone were $0.1 \mathrm{ng} / \mathrm{ml}, 6.8$ and $11.4 \%$. Cross-reactivities of $69,14,20$, and $8.6 \%$ were previously reported for dihydrotestosterone, $3 \alpha$ and $3 \beta$-androstanediol, and nortestosterone respectively (Gay \& Kerlan 1978, At-Taras et al. 2006b). The sensitivity and intraand interassay CV for estrogen conjugates were $0.2 \mathrm{ng} / \mathrm{ml}, 8.3$ and $10.9 \%$. The sensitivity and intra-assay CV for FSH and $\mathrm{LH}$ were 1 and $0.25 \mathrm{ng} / \mathrm{ml}$ and 9.1 and $7.2 \%$ respectively.

\section{Sperm and Sertoli cell counts, cell proliferation, and aromatase activity}

One gram samples of testis were homogenized with $20 \mathrm{ml}$ sterile, aqueous $0.9 \% \mathrm{NaCl} / 0.05 \%$ Triton $\mathrm{X}-100$ at room temperature for $3 \mathrm{~min}$ using a Potter Elvehjem tissue grinder (Amann \& Lambiase 1969, McCarthy et al. 2006). The homogenizer was rinsed, the fluid added to the homogenate, and the total volume measured. Average cell density was determined from a minimum of three counts from hemocytometer grids that were within $10 \%$ of each other and total numbers determined by multiplying cell density by total volume. Sertoli cell numbers per testis were determined as described previously (At-Taras et al. 2006a) using GATA4 labeling of $25 \mu \mathrm{m}$ sections from paraffin blocks and the CASTGrid system. Proliferation rate of Sertoli cells was assessed using immunohistochemical detection of phosphorylated histone 3 as a marker for proliferating cells in $5 \mu \mathrm{m}$ paraffin sections (Brenner et al. 2003). The primary antibody (SC-8656; Santa Cruz Biotechnology, Inc., Santa Cruz, CA, USA) was used at 1:400 dilution in Tris-buffered saline and bound antibody visualized with a goat antibody to rabbit IgG followed by signal amplification and use of 3-amino-9-ethylcarbazole as a chromagen (Vectastain Elite ABC kit, PK6101 and SK4200; Vector Laboratories, Burlingame, CA, USA). Proliferation rate was determined after evaluating 500 Sertoli cells and expressed as a percentage. Aromatase activities were conducted as described and reported previously (Conley et al. 2002, Corbin et al. 2003).

\section{Statistical analysis}

Data were subjected to ANOVA using SAS statistical programs (Proc MIXED; SAS Institute, Cary, NC, USA). Litter was considered a random factor and treatment as a fixed factor. When necessary for normality constraints ( $\mathrm{LH}$ values at 12 and 14 weeks, tissue $E_{2}$ values at 16 and 20 weeks, and tissue estrogen conjugate values at 20 weeks), data were subjected to $\log$ transformation and reported $P$ values are from the transformed data. Differences between means were evaluated using linear contrasts. The $P$ values $<0.05$ were considered significant.

\section{Declaration of interest}

The authors declare that there is no conflict of interest that could be perceived as prejudicing the impartiality of the research reported.

\section{Funding}

Research was supported by W K Kellogg Endowment, National Research Initiative Competitive Grant 2008-35203-19082 from USDA National Institute of Food and Agriculture to T Berger, A Conley, and J F Roser and USDA NIFA Multistate Research Project W2171. The authors gratefully acknowledge the infrastructure support of the Department of Animal Science, College of Agricultural and Environmental Sciences, and the California Agricultural Experiment Station of the University of California-Davis. 


\section{Acknowledgements}

Expert assistance from Kent Parker, Barbara J Nitta-Oda, $\mathrm{C}$ Jo Corbin, and Lil Sibley greatly contributed to the completion of this research. Assistance of Erin Legacki, Kimberley Katleba, Francesca La Piana, Jennie Hughes, and Valerie Guerrero in collecting tissue samples is greatly appreciated. Donations of semen from PIC, USA to maintain genetic line is also appreciated.

\section{References}

Amann RP \& Lambiase JT Jr 1969 The male rabbit. 3. Determination of daily sperm production by means of testicular homogenates. Journal of Animal Science 28 369-374

At-Taras EE, Berger T, McCarthy MJ, Conley AJ, Nitta-Oda BJ \& Roser JF 2006a Reducing estrogen synthesis in developing boars increases testis size and total sperm production. Journal of Andrology 27 552-559. (doi:10.2164/jandrol.05195)

At-Taras EE, Conley AJ, Berger T \& Roser JF $2006 b$ Reducing estrogen synthesis does not affect gonadotropin secretion in the developing boar. Biology of Reproduction 74 58-66. (doi:10.1095/biolreprod.105.043760)

Berger T, McCarthy M, Pearl CA, At-Taras E, Roser JF \& Conley A 2008 Reducing endogenous estrogens during the neonatal and juvenile periods affects reproductive tract development and sperm production in postpuberal boars. Animal Reproduction Science 109 218-235. (doi:10.1016/j.anireprosci.2007.10.003)

Berndtson WE, Igboeli G \& Parker WG 1987 The numbers of Sertoli cells in mature Holstein bulls and their relationship to quantitative aspects of spermatogenesis. Biology of Reproduction 37 60-67. (doi:10.1095/ biolreprod37.1.60)

Brenner RM, Slayden OD, Rodgers WH, Critchley HO, Carroll R, Nie XJ \& Mah K 2003 Immunocytochemical assessment of mitotic activity with an antibody to phosphorylated histone $\mathrm{H} 3$ in the macaque and human endometrium. Human Reproduction 18 1185-1193. (doi:10.1093/ humrep/deg255)

Conley A, Mapes S, Corbin CJ, Greger D \& Graham S 2002 Structural determinants of aromatase cytochrome p450 inhibition in substrate recognition site-1. Molecular Endocrinology 16 1456-1468. (doi:10.1210/me.16.7.1456)

Corbin CJ, Trant JM, Walters KW \& Conley AJ 1999 Changes in testosterone metabolism associated with the evolution of placental and gonadal isozymes of porcine aromatase cytochrome P450. Endocrinology 140 5202-5210. (doi:10.1210/en.140.11.5202)

Corbin CJ, Moran FM, Vidal JD, Ford JJ, Wise T, Mapes SM, Njar VC, Brodie AM \& Conley AJ 2003 Biochemical assessment of limits to estrogen synthesis in porcine follicles. Biology of Reproduction 69 390-397. (doi:10.1095/biolreprod.103.015578)

Corbin CJ, Berger T, Ford J, Roselli CE, Sienkiewicz W, Trainor BC, Roser JF, Vidal JD, Harada N \& Conley AJ 2009 Porcine hypothalamic aromatase cytochrome P450: isoform characterization, sex-dependent activity, regional expression, and regulation by enzyme inhibition in neonatal boars. Biology of Reproduction 81 388-395. (doi:10.1095/ biolreprod.109.076331)

Ford JJ 1983 Serum estrogen concentrations during postnatal development in male pigs. Proceedings of the Society for Experimental Biology and Medicine 174 160-164. (doi:10.3181/00379727-174-41719)

Ford JJ, Rohrer GA, Nonneman DJ, Lunstra DD \& Wise TH 2010 Association of allelic variants of thyroid-binding globulin with puberty in boars and responses to hemicastration. Animal Reproduction Science 119 228-234. (doi:10.1016/j.anireprosci.2009.11.007)

Franca LR, Silva VA Jr, Chiarini-Garcia H, Garcia SK \& Debeljuk L 2000 Cell proliferation and hormonal changes during postnatal development of the testis in the pig. Biology of Reproduction 63 1629-1636. (doi:10. 1095/biolreprod63.6.1629)

Gay VL \& Kerlan JT 1978 Serum LH and FSH following passive immunization against circulating testosterone in the intact male rat and in orchidectomized rats bearing subcutaneous silastic implants of testosterone. Archives of Andrology 1 257-266. (doi:10.3109/014850 17808988345)
Hess RA, Cooke PS, Bunick D \& Kirby JD 1993 Adult testicular enlargement induced by neonatal hypothyroidism is accompanied by increased Sertoli and germ cell numbers. Endocrinology 132 2607-2613. (doi:10.1210/en.132.6.2607)

Jansen HT, Kirby JD, Cooke PS, Arambepola N \& Iwamoto GA 2007 Impact of neonatal hypothyroidism on reproduction in the male hamster, Mesocricetus auratus. Physiology \& Behavior 90 771-781. (doi:10.1016/ j.physbeh.2006.12.017)

Joyce KL, Porcelli J \& Cooke PS 1993 Neonatal goitrogen treatment increases adult testis size and sperm production in the mouse. Journal of Andrology 14 448-455

Klobucar I, Kosec M, Cebulj-Kadunc N \& Majdic G 2003 Postnatal hypothyroidism does not affect prepubertal testis development in boars. Reproduction in Domestic Animals 38 193-198. (doi:10.1046/j.14390531.2003.00423.x)

Korenman SG, Stevens RH, Carpenter LA, Robb M, Niswender GD \& Sherman BM 1974 Estradiol radioimmunoassay without chromatography: procedure, validation and normal values. Journal of Clinical Endocrinology and Metabolism 38 718-720. (doi:10.1210/jcem38-4-718)

Kosco MS, Bolt DJ, Wheaton JE, Loseth KJ \& Crabo BG 1987 Endocrine responses in relation to compensatory testicular growth after neonatal hemicastration in boars. Biology of Reproduction 36 1177-1185. (doi:10.1095/biolreprod36.5.1177)

Lunstra DD, Wise TH \& Ford J 2003 Sertoli cells in the boar testis: changes during development and compensatory hypertrophy after hemicastration at different ages. Biology of Reproduction 68 140-150. (doi:10.1095/ biolreprod.102.006510)

McCarthy MJ, At-Taras EE, Pearl CA, Nitta-Oda BS, Roser JF, Conley AJ \& Berger T 2006 Suppression of endogenous estrogen during development affects porcine epididymal sperm maturation. Molecular Reproduction and Development 73 1122-1128. (doi:10.1002/mrd.20519)

McCoard SA, Lunstra DD, Wise TH \& Ford JJ 2001 Specific staining of Sertoli cell nuclei and evaluation of Sertoli cell number and proliferative activity in Meishan and White Composite boars during the neonatal period. Biology of Reproduction 64 689-695. (doi:10.1095/biolreprod64.2.689)

Moran FM, Ford JJ, Corbin CJ, Mapes SM, Njar VC, Brodie AM \& Conley AJ 2002 Regulation of microsomal P450, redox partner proteins, and steroidogenesis in the developing testes of the neonatal pig. Endocrinology 143 3361-3369. (doi:10.1210/en.2002-220329)

Putra DK \& Blackshaw AW 1982 Morphometric studies of compensatory testicular hypertrophy in the rat after hemicastration. Australian Journal of Biological Sciences 35 287-293.

Putra DK \& Blackshaw AW 1985 Quantitative studies of compensatory testicular hypertrophy following unilateral castration in the boar. Australian Journal of Biological Sciences 38 429-434.

Ramesh R, Pearl CA, At-Taras E, Roser JF \& Berger T 2007 Ontogeny of androgen and estrogen receptor expression in porcine testis: effect of reducing testicular estrogen synthesis. Animal Reproduction Science 102 286-299. (doi:10.1016/j.anireprosci.2006.10.025)

Schwarzenberger F, Toole GS, Christie HL \& Raeside JI 1993 Plasma levels of several androgens and estrogens from birth to puberty in male domestic pigs. Acta Endocrinologica 128 173-177.

Sharpe RM, McKinnell C, Kivlin C \& Fisher JS 2003 Proliferation and functional maturation of Sertoli cells, and their relevance to disorders of testis function in adulthood. Reproduction 125 769-784. (doi:10.1530/ rep.0.1250769)

Tarn CY, Rosenkrans CF Jr, Apple JK \& Kirby JD 1998 Effects of 6-N-propyl2-thiouracil on growth, hormonal profiles, carcass and reproductive traits of boars. Animal Reproduction Science 50 81-94. (doi:10.1016/S03784320(97)00091-2)

Wohlfahrt-Veje C, Main KM \& Skakkebaek NE 2009 Testicular dysgenesis syndrome: foetal origin of adult reproductive problems. Clinical Endocrinology 71 459-465. (doi:10.1111/j.1365-2265.2009.03545.x)

Received 3 December 2011

First decision 9 January 2012

Revised manuscript received 22 January 2012

Accepted 21 February 2012 